\title{
Differential Susceptibility of Nine Cucurbit Species to the Foliar Blight and Crown Canker Phases of Gummy Stem Blight
}

\author{
Anthony P. Keinath, Coastal Research and Education Center, Clemson University, Charleston, SC 29414-5329
}

\begin{abstract}
Keinath, A. P. 2014. Differential susceptibility of nine cucurbit species to the foliar blight and crown canker phases of gummy stem blight. Plant Dis. 98:247-254.

Eighteen cucurbit cultivars representing five genera, nine species, and 17 horticultural types were inoculated with Didymella bryoniae in field plots in Charleston, SC, in autumn 2008, autumn 2009, and spring 2011 to determine susceptibility to gummy stem blight. In each year, gummy stem blight cankers occurred more frequently on crowns or main stems of 'Athena' muskmelon (Cucumis melo) and 'Green Striped Cushaw' squash (Cucurbita argyrosperma) than on all other cultivars except 'Rocio' honeydew (Cucumis melo) in 2009, and bottle gourd (Lagenaria siceraria) and Ojakkyo citron (Citrullus lanatus var. citroides) in 2011. Cucurbita moschata was highly resistant to stem cankers. Severity of gummy stem blight on foliage was moderate to

severe in autumn 2009, mild to severe in autumn 2008, and very mild in spring 2011 (due to unusually dry weather). Watermelon (Citrullus lanatus var. lanatus) and melon were the most susceptible to foliar blight in 2008 and 2009. In all 3 years, 'Cheese' and 'Bugle' squash (both Cucurbita moschata), and 'Judgment III' and 'Lioness' summer squash (C. pepo) were among the cultivars with the least diseased leaf area. C. moschata, C. pepo, C. maxima, and Luffa cylindrica (smooth loofah) were significantly less susceptible to foliar blight than Cucumis melo and three Citrullus lanatus cultivars in 2008 and 2009. This study also is the first documentation of susceptibility of Cucurbita argyrosperma to gummy stem blight.
\end{abstract}

Cucurbits are members of the Cucurbitaceae family, an important crop group that was worth $\$ 35$ billion worldwide in 2011 (8). The four most commonly cultivated cucurbit crops are watermelon (Citrullus lanatus (Thunb.) Matsum. \& Nakai), cucumber (Cucumis sativus L.), melon (Cucumis melo L.), and squash $(\mathrm{Cu}$ curbita pepo L., C. maxima Duch. ex. Lam., C. moschata Duch. ex Poir, and the less common $C$. argyrosperma Huber) $(8,26)$. These four types of crops were produced on 8.6 million ha and yielded 221 million $\mathrm{Mg}$ in 2011, which accounted for $15 \%$ of the area and $20 \%$ of the weight of global vegetable and melon production (8). Among other cucurbits of regional importance are bottle gourd (Lagenaria siceraria (Molina) Stand.), smooth loofah (Luffa cylindrica (L.) M.J. Roehm), and citron (Citrullus lanatus var. citroides (Bailey) Mansf.) (26).

The cucurbit disease gummy stem blight, caused by the ascomycete Didymella bryoniae (Auersw.) Rehm, is present in all regions of the world where cucurbits are grown $(18,25)$. Symptoms of gummy stem blight include water-soaked and necrotic spots on leaves and other aboveground plant parts that expand rapidly during periods of prolonged leaf wetness to blight entire plants (34). In the eastern United States, gummy stem blight causes losses on watermelon, pickling cucumber, and, occasionally, other cucurbits $(15,20,35)$. In Europe, the most commonly affected hosts are glasshouse cucumber, glasshouse melon, and oilseed pumpkin (Cucurbita pepo subsp. pepo var. styriaca) $(5,6,10,32,38)$. D. bryoniae has been found on smooth loofah, bottle gourd, and pumpkin (C. maxima) in tropical environments $(2,12,28,37)$. Citron Plant Introduc-

\section{Corresponding author: A. P. Keinath, E-mail: tknth@clemson.edu}

This material is based upon work supported by NIFA/USDA under project number SC-1700446. Technical Contribution Number 6129 of the Clemson University Experiment Station.

* The $\boldsymbol{e}$-Xtra logo stands for "electronic extra" and indicates that Figures 1 and 2 appear in color in the online edition.

Accepted for publication 4 September 2013.

http://dx.doi.org/10.1094/PDIS-05-13-0510-RE

(C) 2014 The American Phytopathological Society tion (PI) lines ranged from susceptible to resistant when inoculated in the greenhouse and field (11). Yellow summer squash $(C$. pepo subsp. ovifera) is considered one of the few-if not the onlycucurbit that is resistant to gummy stem blight (33). When grown in infested soil in rotation with pickling cucumber, 'Yellow Crookneck' squash had no symptoms of foliar infection even though severity on cucumber was 10 to $43 \%$. If differences in susceptibility exist among cucurbits, this information could be used to refine spray programs and adjust the frequency or type of fungicide applications for control of gummy stem blight.

In addition to foliar blighting, water-soaked or dry cankers of gummy stem blight may form on various cucurbits on the crowns, the growing point from which main vines originate, or on stems or vines. Cankers can occur frequently on muskmelon and watermelon in the field $(12,17,24,31,36,40)$. van Steeklenburg (38) observed that stem lesions developed frequently on greenhouse cucumber from peduncle stubs left after fruit were cut from vines. Severe cankers also were observed on pumpkin-type $C$. maxima in Tanzania (12). The frequency of crown cankers on different cucurbits could have important implications for survival of the pathogen between cucurbit crops, because $D$. bryoniae overwinters on or in cucurbit debris $(4,9,38)$. D. bryoniae survived three to four times longer on thick, cankered crowns of muskmelon than on thin, diseased vines of watermelon $(16,17)$.

Several researchers have compared the susceptibility of cucurbit species and genera to gummy stem blight under greenhouse or field conditions. In Trinidad, D. bryoniae was isolated from various cucurbits, including watermelon, cucumber, pumpkin, and squash (listed only as Cucurbita sp.), and smooth loofah; in the greenhouse, isolates from watermelon were pathogenic on the wounded foliage of all of these hosts as well as cucumber, melon, and angled loofah (L. acutangula) (2). In Brazil, watermelon, melon, cucumber, three horticultural types of C. pepo, and loofah (L. purgans) were susceptible when seedling stems were wounded and inoculated in the greenhouse (7). In the first published comparison of the susceptibility of different cucurbits to vine cankers of gummy stem blight, watermelon and muskmelon were much more susceptible than cucumber, pumpkin (C. pepo), squash (C. maxima), bottle gourd, or smooth loofah (9). Chiu and Walker (4) reported that cankers were more severe on vines of muskmelon than on watermelon, cucumber, and C. maxima Hubbard in the field; acorn 
squash (C. pepo) was resistant, even when wounded and inoculated. In the greenhouse, cankers also formed on vines of $C$. maxima, Lagenaria siceraria, and C. pepo (pumpkin and zucchini) when wounded and inoculated but no cankers developed on summer squash (4). The authors commented, however, that low humidity in the greenhouse may have reduced infection. Only the test in the most recent study, done in Brazil (7), was repeated, and this was an inoculation experiment in a greenhouse. In none of these studies were the data analyzed statistically $(2,4,7,9)$. No reports included information on susceptibility of $C$. moschata, C. argyrosperma, or citron to gummy stem blight. Thus, there is a need to determine the relative susceptibility of multiple cucurbit species and genera under field conditions that are conducive to infection by $D$. bryoniae, so that the results are applicable to commercially grown cucurbit crops.

The objectives of this study were to determine whether the cucurbits cultivated commonly in the United States differ in susceptibility to the crown canker and foliar phases of gummy stem blight under field conditions. Gummy stem blight was assessed by visually rating the incidence and severity of disease, and recovering the pathogen from diseased tissue by culturing.

\section{Materials and Methods}

Field experiments. Three experiments were done at the Clemson University Coastal Research and Education Center in Charleston, SC. Eighteen cultivars of cucurbits were selected to represent 17 horticultural types, 11 taxa, nine species, five genera, three subtribes, two tribes, and one subfamily of the Cucurbitaceae family (26). Cultivars that had resistance to powdery mildew were selected whenever possible (Table 1).

The experimental design was a randomized complete block with five replications in autumn 2008, and four replications in each of autumn 2009 and spring 2011. The same field was used in 2008 and 2011 and a different field was used in 2009. The fields used in autumn 2008 and 2009 were fallow in the spring of each year. The field used in 2011 was cropped to watermelon in autumn 2010; gummy stem blight was present throughout the field. Each plot was a single row of a raised bed, $0.9 \mathrm{~m}$ wide on a 3.6-m center, covered with polyethylene mulch that was colored white-on-black in the autumn and black in the spring. Each plot was $9.1 \mathrm{~m}$ long with 2.4 $\mathrm{m}$ of nonplanted space between adjacent plots within rows. Seven transplants were spaced $1.2 \mathrm{~m}$ apart within each plot (Table 2). Weeds, insects, powdery mildew, and downy mildew were managed with recommended practices (21). Downy mildew was present on 'Green Striped Cushaw', 'Bugle', 'Aladdin', 'Judgment III', and 'Taybelle PM' by the end of the season in 2008; the disease was severe on Green Striped Cushaw but limited on the other cultivars.

In all years, plants were inoculated twice with a 1:1 mixture of two isolates of $D$. bryoniae that were recovered from diseased muskmelon and watermelon in South Carolina (Table 2). In 2008 and 2009 , a suspension of $5 \times 10^{5}$ spores $/ \mathrm{ml}$, prepared in sucrosecasein solution, was used (21). In 2011, a suspension of mycelia in sucrose-casein solution was used. Inoculum was applied to the crowns of plants with a $\mathrm{CO}_{2}$ backpack sprayer at dusk (approximately 8:00 P.M.). In 2008, plants were overhead irrigated just prior to inoculation and two to three times per week after inoculation to provide additional periods of leaf wetness. In 2009 and 2011, plants were misted in the morning and evening with overhead, lowpressure, mini-wobbler sprinklers (Senninger Irrigation; Table 2).

After inoculation, incidences of gummy stem blight and crown cankers on plants were determined by examining leaves and stems, respectively, with a $\times 10$ hand lens for the presence of pycnidia or

Table 1. Cucurbit taxa and cultivars evaluated for susceptibility to gummy stem blight in the field in South Carolina in 2008, 2009, and 2011

\begin{tabular}{|c|c|c|c|c|c|}
\hline Genus & Species & Subspecific taxon ${ }^{z}$ & Cultivar & Horticultural type & Powdery mildew resistance \\
\hline Citrullus & lanatus & var. lanatus & Crimson Sweet & Watermelon & No \\
\hline Citrullus & lanatus & var. lanatus & Mickey Lee & Watermelon & No \\
\hline Citrullus & lanatus & var. citroides & Ojakkyo & Citron & No \\
\hline Сиситis & melo & subsp. melo & Athena & Muskmelon & Yes \\
\hline Cucumis & melo & subsp. melo & Rocio & Honeydew & Yes \\
\hline Сиситis & sativus & (none) & Marketmore & Slicing cucumber & Yes \\
\hline Cucumis & sativus & (none) & Colt & Pickling cucumber & Yes \\
\hline Cucurbita & argyrosperma & subsp. argyrosperma & Green Striped Cushaw & Winter squash & No \\
\hline Cucurbita & maxima & (none) & Hubbard & Winter squash & No \\
\hline Cucurbita & maxima & (none) & Big Max & Giant pumpkin & No \\
\hline Cucurbita & moschata & (none) & Bugle & Butternut squash & Yes \\
\hline Cucurbita & moschata & (none) & Cheese & Winter squash & No \\
\hline Cucurbita & реро & subsp. pepo & Aladdin & Pumpkin & Yes \\
\hline Cucurbita & реро & subsp. pepo & Judgment III & Zucchini squash & Yes \\
\hline Cucurbita & реро & subsp. ovifera & Lioness & Yellow summer squash & Yes \\
\hline Cucurbita & реро & subsp. ovifera & Taybelle PM & Acorn squash & Yes \\
\hline Luffa & cylindrica & (none) & (none) & Smooth loofah & No \\
\hline Lagenaria & siceraria & subsp. siceraria & (none) & Bottle gourd & No \\
\hline
\end{tabular}

y Cucurbits were transplanted into field plots, inoculated with Didymella bryoniae, and rated for symptoms of gummy stem blight in autumn 2008, autumn 2009, and spring 2011.

${ }^{\mathrm{z}}$ According to Robinson and Decker-Walters (26).

Table 2. Key dates and environmental conditions in Charleston, SC, during field experiments in which 18 cucurbit cultivars were inoculated with Didymella bryoniae in 2008, 2009, and 2011

\begin{tabular}{|c|c|c|c|c|c|c|c|c|}
\hline Season, year & Transplanting date & Inoculation dates & First sampling date & Last sampling date & $\underset{\left({ }^{\circ} \mathbf{C}\right)^{\mathrm{w}, \mathbf{x}}}{\operatorname{Max}}$ & $\underset{\left({ }^{\circ} \mathbf{C}\right)^{\mathrm{w}, \mathrm{x}}}{\operatorname{Min}}$ & $\underset{(\mathbf{m m})^{\mathrm{x}}}{\text { Rainfall }}$ & $\begin{array}{l}\text { Misting } \\
\text { (h/day) }\end{array}$ \\
\hline Autumn 2008 & 31 July 2008 & $\begin{array}{l}16 \text { September } 2008 \\
8 \text { October } 2008\end{array}$ & 18 September 2008 & 23 October 2008 & 23.6 & 10.4 & 333 & 0 \\
\hline Autumn 2009 & 21 July 2009 & $\begin{array}{l}17 \text { August } 2009 \\
31 \text { August } 2009\end{array}$ & 22 September 2009 & 3 November 2009 & 27.4 & 17.3 & 134 & $1^{y}$ \\
\hline Spring 2011 & 29 March 2011 & $\begin{array}{l}\text { 10 May } 2011 \\
21 \text { May } 2011\end{array}$ & 8 June 2011 & 6 July 2011 & 32.0 & 19.0 & 102 & $1^{\mathrm{z}}$ \\
\hline
\end{tabular}

\footnotetext{
${ }^{\mathrm{w}}$ Mean daily maximum (Max) and minimum (Min) temperatures.

${ }^{\mathrm{x}}$ Between first inoculation and last sampling dates. Weather data were recorded on site.

${ }^{y}$ Misting was done for two 30-min periods each day, beginning at 7:00 P.M. and 7:00 A.M.

${ }^{\mathrm{z}}$ Misting was done as four 15-min periods each day, beginning at 7:00 P.M., 11:00 P.M., 3:00 A.M., and 7:00 A.M.
} 
pseudothecia to verify that symptoms were caused by $D$. bryoniae. Incidences of foliar blight and cankers were calculated separately as percentages of plants in each plot with symptoms. Severity of foliar blight was rated with a 16-point modified Horsfall-Barratt scale as the percent surface area diseased (19). The midpoint value of the percentage range of each rating was used for data analysis.

Three to five leaves, each with several leaf spots that appeared to be from gummy stem blight, were collected from each cultivar four times in 2008 and twice in 2009 (Table 2). Leaves were collected in one block at each sampling time. Ten leaf pieces, cut from 10 individual leaf spots for each cultivar, were cultured to recover $D$. bryoniae, as described previously (17). Fungi growing from the plant tissue were examined and identified based on characteristic morphology $(22,25)$. Isolations were not done in 2011.

Statistical analyses. Incidence of cankers, foliar disease severity, and pathogen recovery data were analyzed with SAS PROC MIXED (SAS version 9.3; SAS Institute Inc.). Percentages were transformed by calculating the arcsine of the square root or simply the square root before analysis to eliminate or minimize effects of inequality of variance among cultivars or non-normality of the data. Cultivar and year were analyzed as fixed effects and blocks were analyzed as random effects. The Satterthwaite option was used to estimate degrees of freedom. Cultivar and year means were compared with $t$ tests of least-squares means evaluated at $P=0.01$. Preplanned, single-degree-of-freedom contrasts were used to compare cucurbit species or genera when there were no significant $(P>$ 0.01 ) differences among cultivars within a species.

Because transformations did not eliminate inequality of variance or non-normality for foliar disease incidence, proportions of plants showing symptoms were analyzed with SAS PROC CATMOD for categorical data, which produces a $\chi^{2}$ statistic to evaluate treatment effects. Proportions were transformed by calculating the logit, and the linear model parameters were estimated using the maximum likelihood option. In order to get models that included proportions of 0.0 or 1.0 (i.e., 0 or $100 \%$ incidence) to converge (i.e., arrive at a unique solution), observed proportions were replaced with a Bayes estimator calculated as $x=(c t+k / r) \times n /(n+k)$, where $x=$ the transformed proportion, $c t=$ count of plants with (or without) symptoms, $r=2$ (for a binary response), $k=$ a constant which was set equal to $r$, and $n=$ total number of plants (30). Contrast statements were written to compare cultivars, species, and genera when treatment effects were significant $(P<0.05)$. When there were no differences $(P>0.01)$ among cultivars within species, contrasts focused on comparisons among species.

\section{Results}

Cultivar-year interactions were significant $(P<0.05)$ for canker and foliar disease incidence and foliar severity; thus, cultivars were compared within years and years were compared within cultivars. Nevertheless, most cultivars displayed consistent susceptibility or resistance across years. The greater incidence of cankers and more severe foliar disease on some cultivars in autumn 2009 compared with autumn 2008 may have been due to the additional leaf wetness provided by the mist system used in 2009 (Table 1). In addition, inoculations were done earlier and rating dates were slightly later in the growing season in 2009 than in 2008; therefore, disease was assessed later in the epidemic and in the trial.

Cankers. Overall incidence of gummy stem blight cankers on crowns or main stems was least in autumn 2008, greatest in autumn 2009, and intermediate in spring 2011 (Table 3). When incidences of crown cankers were compared among years within cultivars, the most distinct patterns were among cultivars, not in pairwise comparisons of years (Table 4). There were no significant differences among years $(P>0.05)$ for the two watermelon cultivars as well as Bugle, Cheese, Aladdin, 'Lioness', and smooth loofah, because these seven cultivars had low incidences of gummy stem blight. For eight other cultivars (the two melon cultivars plus 'Marketmore', Green Striped Cushaw, 'Hubbard', 'Big Max', Judgment III, and Taybelle PM), incidence of crown cankers was greater in 2009 than in 2008 or $2011(P \leq 0.02)$ and incidences did not differ between 2008 and 2011. For 'Colt' pickling cucumber and bottle gourd, disease incidence was greater in 2009 and 2011 than in $2008(P \leq 0.01)$. For citron, incidence was greater in 2011 than in 2008 and $2009(P \leq 0.0002)$.

In each year, gummy stem blight cankers on crowns or main stems occurred more frequently and more extensively on 'Athena'

Table 3. Incidence and severity of gummy stem blight compared within years for 18 cucurbit cultivars inoculated with Didymella bryoniae

\begin{tabular}{|c|c|c|c|c|c|c|c|c|}
\hline \multirow[b]{2}{*}{ Cultivar $^{\mathrm{z}}$} & \multicolumn{3}{|c|}{$\begin{array}{l}\text { Incidence of plants with } \\
\text { crown cankers }(\%)^{\mathrm{x}}\end{array}$} & \multicolumn{2}{|c|}{$\begin{array}{l}\text { Incidence of plants with } \\
\text { leaf symptoms }(\%)^{y}\end{array}$} & \multicolumn{3}{|c|}{$\begin{array}{c}\text { Foliar severity based on } \\
\text { leaf area symptomatic }(\%)^{\mathrm{x}}\end{array}$} \\
\hline & $\begin{array}{l}2 \text { October } \\
2008\end{array}$ & $\begin{array}{l}21 \text { October } \\
2009\end{array}$ & $\begin{array}{l}1 \text { June } \\
2011\end{array}$ & $\begin{array}{l}2 \text { October } \\
2008\end{array}$ & $\begin{array}{l}25 \text { September } \\
2009\end{array}$ & $\begin{array}{l}16 \text { October } \\
2008\end{array}$ & $\begin{array}{l}30 \text { October } \\
2009\end{array}$ & $\begin{array}{c}1 \text { June } \\
2011\end{array}$ \\
\hline Crimson Sweet & $1.9 \mathrm{c}$ & 6.7 ef & 19.2 cde & $100.0 \mathrm{a}$ & $100.0 \mathrm{a}$ & $92.0 \mathrm{a}$ & $100.0 \mathrm{a}$ & $1.0 \mathrm{bcd}$ \\
\hline Mickey Lee & $1.1 \mathrm{c}$ & $18.4 \mathrm{cdef}$ & 21.9 cde & $100.0 \mathrm{a}$ & $100.0 \mathrm{a}$ & $88.7 \mathrm{a}$ & $100.0 \mathrm{a}$ & $1.0 \mathrm{bcd}$ \\
\hline Ojakkyo & $0.0 \mathrm{c}$ & $0.6 \mathrm{f}$ & $43.8 \mathrm{abc}$ & $100.0 \mathrm{a}$ & $93.8 \mathrm{abc}$ & $50.0 \mathrm{~b}$ & $48.2 \mathrm{c}$ & $1.6 \mathrm{abc}$ \\
\hline Athena & $64.9 \mathrm{a}$ & $99.4 \mathrm{a}$ & $78.9 \mathrm{a}$ & $100.0 \mathrm{a}$ & $100.0 \mathrm{a}$ & $91.8 \mathrm{a}$ & $90.1 \mathrm{ab}$ & $1.0 \mathrm{bcd}$ \\
\hline Rocio & $23.2 \mathrm{~b}$ & $96.2 \mathrm{ab}$ & $28.0 \mathrm{bcd}$ & $100.0 \mathrm{a}$ & $100.0 \mathrm{a}$ & $93.0 \mathrm{a}$ & $99.8 \mathrm{ab}$ & $0.6 \mathrm{cde}$ \\
\hline Marketmore & $1.1 \mathrm{c}$ & $37.3 \mathrm{cde}$ & $0.9 \mathrm{de}$ & $100.0 \mathrm{a}$ & $96.9 \mathrm{ab}$ & $66.3 \mathrm{ab}$ & n.d. & $1.6 \mathrm{abc}$ \\
\hline Colt & $0.0 \mathrm{c}$ & 39.6 cde & $23.1 \mathrm{bcd}$ & $48.0 \mathrm{~cd}$ & $73.9 \mathrm{abcd}$ & $21.3 \mathrm{bc}$ & n.d. & $2.3 \mathrm{ab}$ \\
\hline Green Striped Cushaw & $84.9 \mathrm{a}$ & $99.4 \mathrm{a}$ & $60.8 \mathrm{ab}$ & $100.0 \mathrm{ab}$ & $96.9 \mathrm{ab}$ & n.d. & $72.0 \mathrm{~b}$ & $2.4 \mathrm{ab}$ \\
\hline Hubbard & $0.0 \mathrm{c}$ & $59.3 \mathrm{bcd}$ & 4.9 cde & $100.0 \mathrm{a}$ & $96.9 \mathrm{ab}$ & $11.6 \mathrm{c}$ & 20.8 def & $1.0 \mathrm{bcd}$ \\
\hline Big Max & $0.0 \mathrm{c}$ & $63.1 \mathrm{bc}$ & $14.6 \mathrm{cde}$ & $100.0 \mathrm{abc}$ & $92.9 \mathrm{abc}$ & $2.3 \mathrm{c}$ & $34.6 \mathrm{~cd}$ & $4.0 \mathrm{a}$ \\
\hline Bugle & $0.0 \mathrm{c}$ & $0.6 \mathrm{f}$ & $0.0 \mathrm{e}$ & $0.0 \mathrm{e}$ & $28.6 \mathrm{e}$ & $0.6 \mathrm{c}$ & $20.8 \mathrm{def}$ & $0.1 \mathrm{de}$ \\
\hline Cheese & $0.0 \mathrm{c}$ & $0.6 \mathrm{f}$ & $0.0 \mathrm{e}$ & $83.3 \mathrm{abc}$ & $71.0 \mathrm{abcd}$ & $6.7 \mathrm{c}$ & $11.6 \mathrm{f}$ & $0.3 \mathrm{cde}$ \\
\hline Aladdin & $0.0 \mathrm{c}$ & $18.3 \mathrm{cdef}$ & $3.7 \mathrm{de}$ & $52.0 \mathrm{bc}$ & 61.2 bcde & $6.7 \mathrm{c}$ & $32.1 \mathrm{~cd}$ & $1.0 \mathrm{bcd}$ \\
\hline Judgment III & $0.0 \mathrm{c}$ & 24.4 cdef & $0.0 \mathrm{e}$ & $80.0 \mathrm{abc}$ & $25.0 \mathrm{e}$ & $4.2 \mathrm{c}$ & 14.9 ef & 0.3 cde \\
\hline Lioness & $0.0 \mathrm{c}$ & $13.7 \mathrm{def}$ & $0.0 \mathrm{e}$ & $97.1 \mathrm{ab}$ & $23.2 \mathrm{e}$ & $8.0 \mathrm{c}$ & $6.7 \mathrm{f}$ & 0.3 cde \\
\hline Taybelle PM & $0.0 \mathrm{c}$ & $34.7 \mathrm{cde}$ & $0.0 \mathrm{e}$ & $6.7 \mathrm{de}$ & $46.9 \mathrm{de}$ & $3.2 \mathrm{c}$ & n.d. & $0.0 \mathrm{e}$ \\
\hline Loofah & $0.0 \mathrm{c}$ & $12.3 \mathrm{def}$ & $11.3 \mathrm{cde}$ & $92.0 \mathrm{abc}$ & $53.1 \mathrm{cde}$ & $9.0 \mathrm{c}$ & $24.7 \mathrm{de}$ & $1.0 \mathrm{bcd}$ \\
\hline Bottle gourd & $2.1 \mathrm{c}$ & $51.5 \mathrm{~cd}$ & $68.8 \mathrm{ab}$ & $75.0 \mathrm{abc}$ & $89.3 \mathrm{abc}$ & n.d. & n.d. & $1.0 \mathrm{bcd}$ \\
\hline
\end{tabular}

${ }^{\mathrm{x}}$ Each value is the mean of four replications. Means within a column with the same letter are not significantly different, based on least-squares means $t$ tests, $P \leq 0.01$. Values shown were back-transformed from means of data transformed by calculating the arcsine of the square root of proportions before analysis of variance, except for foliar severity in 2009 , which was transformed by calculating the square root of the original percentages; n.d. = no data due to the presence of downy mildew on Green Striped Cushaw (2008), anthracnose on cucumber (2009) and bottle gourd (2008 and 2009), and ozone injury on Taybelle PM (2009).

${ }^{y}$ Each value is the mean of four replications. Means within a column with the same letter are not significantly different, based on contrasts of maximum likelihood estimates of the logit of weighted proportions in categorical data analysis evaluated with $\chi^{2}$ tests, $P \leq 0.01$. Values shown are original nontransformed percentages of symptomatic plants.

${ }^{\mathrm{z}}$ Cultivars are listed in the same order as in Table 1. 
muskmelon and Green Striped Cushaw squash than on all other cultivars, except 'Rocio' honeydew in 2009 and bottle gourd and citron in 2011. Cankers on the most susceptible cultivars displayed the characteristic amber, gummy exudate (Fig. 1A). Fruiting bodies were present on most cankers (Fig 1). In 2008, cankers formed on only 7 of the 18 cultivars, primarily on Athena, Green Striped Cushaw, and Rocio (Table 3). In 2009, cankers formed on all Athena and Green Striped Cushaw plants, on most plants of Rocio, and on some plants of all other cultivars except citron, Bugle, and Cheese. Big Max and Hubbard had the next greatest incidence of cankers, followed by bottle gourd, cucumber, and Taybelle PM acorn squash. In both 2008 and 2009, cankers occurred more frequently on $C$. melo and $C$. argyrosperma than all other species (single-degree-of-freedom contrasts, $P \leq 0.01$ ). In 2011, Athena, bottle gourd, Green Striped Cushaw, and citron had the greatest incidence of cankers. Rocio had fewer cankers than Athena in 2008 and $2011(P \leq 0.01)$ but, otherwise, cultivars within the same species did not differ in susceptibility to crown cankers. In each year, melons had more cankers than watermelon, cucumber, and C. moschata. C. argyrosperma had a greater canker incidence than the other three Cucurbita spp., cucumber, and smooth loofah (singledegree-of-freedom contrasts, $P \leq 0.01$; Table 3 ).

In all three experiments, Bugle and Cheese (cultivars of $C$. moschata) were highly resistant to stem cankers; no cankers developed on any plants (Table 3). (The value of 0.6 in 2009 resulted from back-transformed means.) Canker incidence on smooth loofah and Aladdin, Judgment III, Lioness, and Taybelle PM (the four C. pepo cultivars) also was minimal $(<15 \%)$ in all three experiments, with the exception of a moderate incidence on Taybelle PM acorn squash in 2009 (Fig. 1B). Canker incidence on C. moschata, $C$. pepo, smooth loofah, cucumber, and $C$. maxima did not differ significantly in 2008 and 2011 (single-degree-of-freedom contrasts, $P$ $\leq 0.01$ ). Watermelon also did not differ from smooth loofah, cucumber, and C. maxima in 2008 and 2011 for incidence of cankers. In 2009, canker incidence did not differ among $C$. moschata, smooth loofah, watermelon, and citron. Watermelon and citron did not differ in canker incidence in any year.

Foliar blight. When the proportion of plants with foliar symptoms of gummy stem blight was compared, 14 of the 18 cultivars were placed in the same susceptibility groups in both 2008 and 2009 (Table 2). Gummy stem blight was present on leaves of $\geq 94 \%$ of the plants of eight cultivars, including all cultivars of watermelon, citron, and melon, plus Marketmore, Green Striped Cushaw, and Hubbard. Big Max and Cheese were grouped with the more severely diseased cultivars in both years (Fig. 2A). Aladdin had intermediate incidence in both years, which was less than that of both melon cultivars. Likewise, foliar blight incidence was less on Taybelle PM and Bugle in both years than on the eight most susceptible cultivars listed above. Within C. moschata, Bugle, a hybrid, had less foliar disease incidence than Cheese, an heirloom cultivar, in both years. The four cultivars that changed rankings among years were Colt, which had a greater incidence in 2009 than in 2008; and Judgment III, Lioness, and smooth loofah, which grouped with the most susceptible cultivars in 2008 but with the least susceptible cultivars in 2009.

Severity of gummy stem blight on foliage was minimal in spring 2011, minimal to severe in autumn 2008, and moderate to severe in autumn 2009. In 2009, gummy stem blight severity increased rapidly in the last 6 weeks of the experiment, particularly during the final 3 weeks. Precipitation in spring 2011 was below normal (Table 2). Severity of gummy stem blight was greater in 2009 than in 2011 for all cultivars (least-squares means $t$ tests, $P \leq 0.0001$ ) except Lioness $(P=0.02)$. There were no consistent patterns when disease severity in years 2008 and 2009 or 2008 and 2011 were compared within cultivars (Table 4).

In 2008, severity was almost $90 \%$ or greater on melons and watermelon, and minimal $(<12 \%)$ on all Cucurbita cultivars and smooth loofah (Table 3; Fig. 2B). Severity was significantly greater on melons, watermelon, Marketmore slicing cucumber, and citron than on all other cultivars except Colt pickling cucumber $(P \leq$ $0.01)$. In addition, severity was greater on melons and watermelon than on citron. Symptoms were less severe on all Cucurbita cultivars than on other cultivars except Colt. Although gummy stem blight was present on leaves of Green Striped Cushaw and bottle gourd, the symptoms could not be rated accurately because of downy mildew caused by Pseudoperonospora cubensis on the former and anthracnose caused by Colletotrichum orbiculare on the latter.

In 2009, all plants of both watermelon cultivars and all but one plant of Rocio honeydew were killed by gummy stem blight by the end of the experiment. Watermelon and melons had significantly more diseased foliage than all other cultivars except Green Striped

Table 4. Comparisons across years of incidence of crown cankers and severity of foliar blighting of gummy stem blight on 18 cucurbit cultivars inoculated with Didymella bryoniae ${ }^{y}$

\begin{tabular}{|c|c|c|c|c|c|c|}
\hline \multirow[b]{2}{*}{ Cultivar $^{\mathbf{z}}$} & \multicolumn{3}{|c|}{ Incidence of plants with crown cankers (\%) } & \multicolumn{3}{|c|}{ Foliar severity based on leaf area symptomatic (\%) } \\
\hline & 2 October 2008 & 21 October 2009 & 1 June 2011 & 16 October 2008 & 30 October 2009 & 1 June 2011 \\
\hline Crimson Sweet & $1.9 \mathrm{~A}$ & $6.7 \mathrm{~A}$ & $19.2 \mathrm{~A}$ & $92.0 \mathrm{~b}$ & $100.0 \mathrm{a}$ & $1.0 \mathrm{c}$ \\
\hline Mickey Lee & $1.1 \mathrm{~A}$ & $18.4 \mathrm{~A}$ & $21.9 \mathrm{~A}$ & $88.7 \mathrm{~b}$ & $100.0 \mathrm{a}$ & $1.0 \mathrm{c}$ \\
\hline Ojakkyo & $0.0 \mathrm{~B}$ & $0.0 \mathrm{~B}$ & $43.8 \mathrm{~A}$ & $50.0 \mathrm{a}$ & $48.2 \mathrm{a}$ & $1.6 \mathrm{~b}$ \\
\hline Athena & $64.9 \mathrm{~B}$ & $100.0 \mathrm{~A}$ & $78.9 \mathrm{~B}$ & $91.8 \mathrm{a}$ & $90.1 \mathrm{a}$ & $1.0 \mathrm{~b}$ \\
\hline Rocio & $23.2 \mathrm{~B}$ & $96.2 \mathrm{~A}$ & $28.0 \mathrm{~B}$ & $93.0 \mathrm{a}$ & $99.8 \mathrm{a}$ & $0.6 \mathrm{~b}$ \\
\hline Marketmore & $1.1 \mathrm{~B}$ & $37.3 \mathrm{~A}$ & $0.9 \mathrm{~B}$ & n.d. & n.d. & n.d. \\
\hline Colt & $0.0 \mathrm{~B}$ & $39.6 \mathrm{~A}$ & $23.1 \mathrm{~A}$ & n.d. & n.d. & n.d. \\
\hline $\begin{array}{l}\text { Green Striped } \\
\text { Cushaw }\end{array}$ & $84.9 \mathrm{AB}$ & $100.0 \mathrm{~A}$ & $60.8 \mathrm{~B}$ & n.d. & n.d. & n.d. \\
\hline Hubbard & $0.0 \mathrm{~B}$ & $59.3 \mathrm{~A}$ & 4.9 $\mathrm{AB}$ & $11.6 \mathrm{ab}$ & $20.8 \mathrm{a}$ & $1.0 \mathrm{~b}$ \\
\hline Big Max & $0.0 \mathrm{~B}$ & $63.1 \mathrm{~A}$ & $14.6 \mathrm{AB}$ & $2.3 \mathrm{~b}$ & $34.6 \mathrm{a}$ & $4.0 \mathrm{~b}$ \\
\hline Bugle & $0.0 \mathrm{~A}$ & $0.0 \mathrm{~A}$ & $0.0 \mathrm{~A}$ & $0.6 \mathrm{~b}$ & $20.8 \mathrm{a}$ & $0.1 \mathrm{~b}$ \\
\hline Cheese & $0.0 \mathrm{~A}$ & $0.0 \mathrm{~A}$ & $0.0 \mathrm{~A}$ & $6.7 \mathrm{ab}$ & $11.6 \mathrm{a}$ & $0.3 \mathrm{~b}$ \\
\hline Aladdin & $0.0 \mathrm{~A}$ & $18.3 \mathrm{~A}$ & $3.7 \mathrm{~A}$ & $6.7 \mathrm{~b}$ & $32.1 \mathrm{a}$ & $1.0 \mathrm{~b}$ \\
\hline Judgment III & $0.0 \mathrm{~A}$ & $24.4 \mathrm{~A}$ & $0.0 \mathrm{~A}$ & $4.2 \mathrm{ab}$ & $14.9 \mathrm{a}$ & $0.3 \mathrm{~b}$ \\
\hline Lioness & $0.0 \mathrm{~A}$ & $13.7 \mathrm{~A}$ & $0.0 \mathrm{~A}$ & $8.0 \mathrm{a}$ & $6.7 \mathrm{ab}$ & $0.3 \mathrm{~b}$ \\
\hline Taybelle PM & $0.0 \mathrm{~B}$ & $34.7 \mathrm{~A}$ & $0.0 \mathrm{~B}$ & n.d. & n.d. & n.d. \\
\hline Loofah & $0.0 \mathrm{~A}$ & $12.3 \mathrm{~A}$ & $11.3 \mathrm{~A}$ & $9.0 \mathrm{ab}$ & $24.7 \mathrm{a}$ & $1.0 \mathrm{~b}$ \\
\hline Bottle gourd & $2.1 \mathrm{~B}$ & $51.5 \mathrm{~A}$ & $68.8 \mathrm{~A}$ & n.d. & n.d. & n.d. \\
\hline
\end{tabular}

${ }^{y}$ Each value is the mean of four replications. Means of incidence (uppercase letters) or severity (lowercase letters) within a row with the same letter are not significantly different, based on least-squares means $t$ tests, $P \leq 0.01$; n.d. = no data; comparisons across years could not be made due to the presence of downy mildew on Green Striped Cushaw (2008), anthracnose on cucumber (2009) and bottle gourd (2008 and 2009), and ozone injury on Taybelle PM (2009).

${ }^{\mathrm{z}}$ Cultivars are listed in the same order as in Tables 1 and 3. 
Cushaw $(P \leq 0.01)$. Green Striped Cushaw had greater disease severity than smooth loofah and all other cultivars of Cucurbita. Citron had almost 50\% severity, which was greater than that of smooth loofah and all Cucurbita cultivars except Big Max and Aladdin. Severity was least on Lioness and Cheese, although severity of gummy stem blight on Judgment III, Bugle, and Hubbard did not differ significantly from these two cultivars. Gummy stem blight could not be rated accurately on the foliage of cucumber and bottle gourd, because anthracnose was present at levels as great as or greater than gummy stem blight. In addition, ozone injury appeared as bleaching of leaf laminas on Taybelle PM acorn squash in early October and became so severe that gummy stem blight could not be rated.

In 2011, the combination of unusually dry weather in May and June and warmer than normal average temperatures in June suppressed gummy stem blight on foliage, despite use of the mist system (Table 2). Nevertheless, Taybelle PM, Bugle, Cheese, Judgment III, and Lioness again had the least severe ratings, as in the other two experiments. Big Max, however, had the greatest severity rating in this experiment.

Overall, there were few differences in gummy stem blight severity among cultivars within a species. In 2009, severity of gummy stem blight was greater on Aladdin pumpkin than on the summer

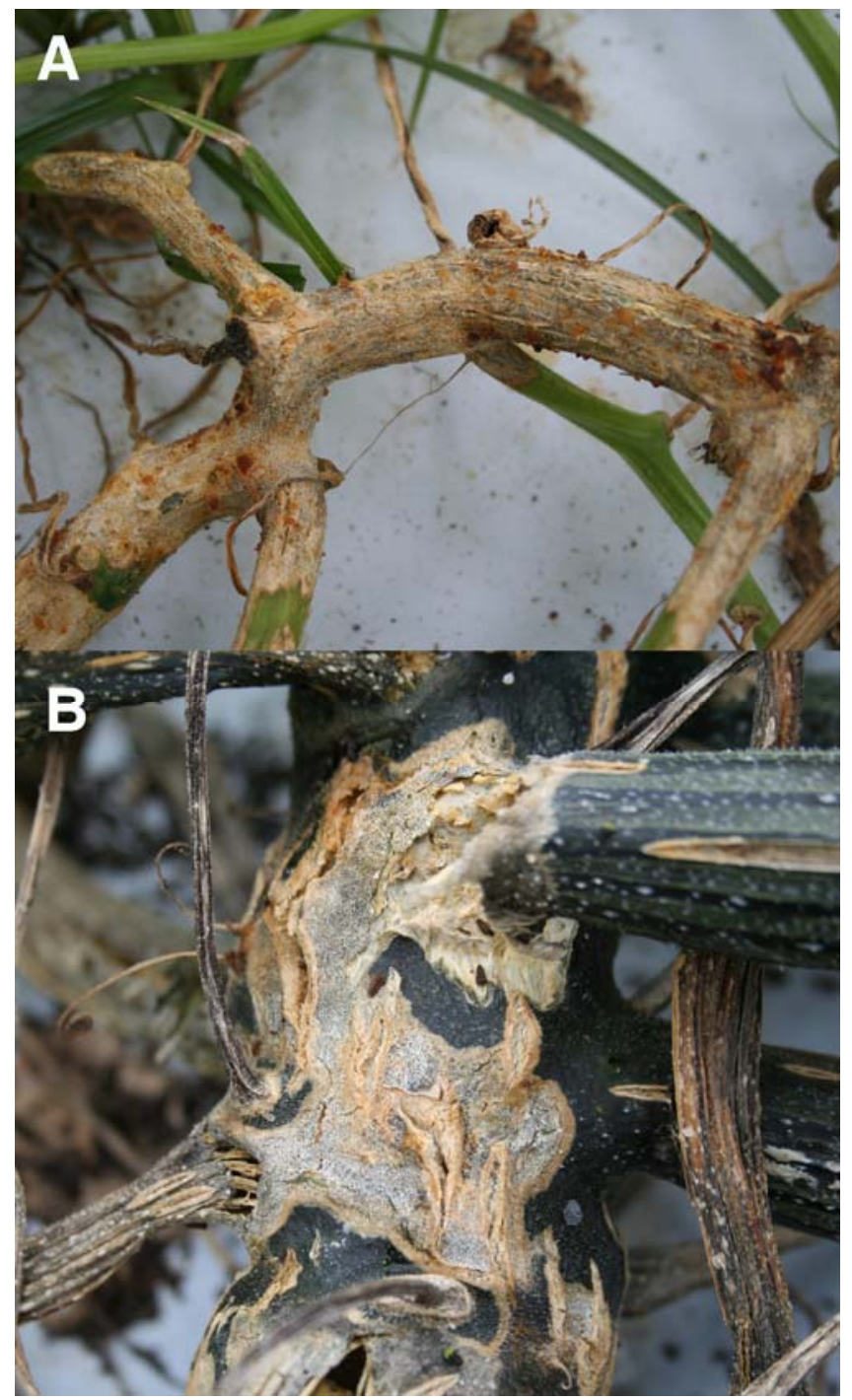

Fig. 1. Canker phase of gummy stem blight with fruiting bodies of Didymella bryoniae. A, Large, tan canker on the main stem and vines of Cucurbita argyrosperma 'Green Striped Cushaw' squash with characteristic, gummy exudate. B, Fissured, bleached canker on the thickened main stem of mature Cucurbita pepo 'Judgment III' zucchini. squash Judgment III and Lioness, which are cultivars of C. pepo (Table 3). In 2011, disease severity was greater on Aladdin than on Taybelle PM acorn squash, which had no leaf spots of gummy stem blight on any plants. In 2011, there also was a significant difference between the two cultivars of C. maxima, because Hubbard had more severe foliar gummy stem blight than Big Max.

In all 3 years, severity of gummy stem blight was significantly less on $C$. moschata cultivars than on all three Citrullus cultivars (watermelon and citron) (single-degree-of-freedom contrasts, $P \leq$ 0.0001). Moreover, disease also was less severe on all $C$. maxima and $C$. pepo cultivars and on smooth loofah than on both cultivars of melon (Cucumis melo) and all three Citrullus cultivars in 2008 and $2009(P \leq 0.0001)$. In no year did the mean severity of gummy stem blight across Cucurbita cultivars differ from severity on smooth loofah (single-degree-of-freedom contrasts, $P \geq 0.42$ ). Gummy stem blight was only half as severe on citron as on watermelon in 2008 and 2009 (Table 3); in 2011, severity ratings on citron and watermelon did not differ.

A few differences in symptoms were observed among cultivars. Although Hubbard and Cheese had high $(>80 \%)$ incidence of foliar gummy stem blight, the leaf spots remained relatively small. These two cultivars had relatively low severity values for foliar blight in $2008(<12 \%)$ and $2009(<25 \%)$ (Table 3). Foliar severity ratings

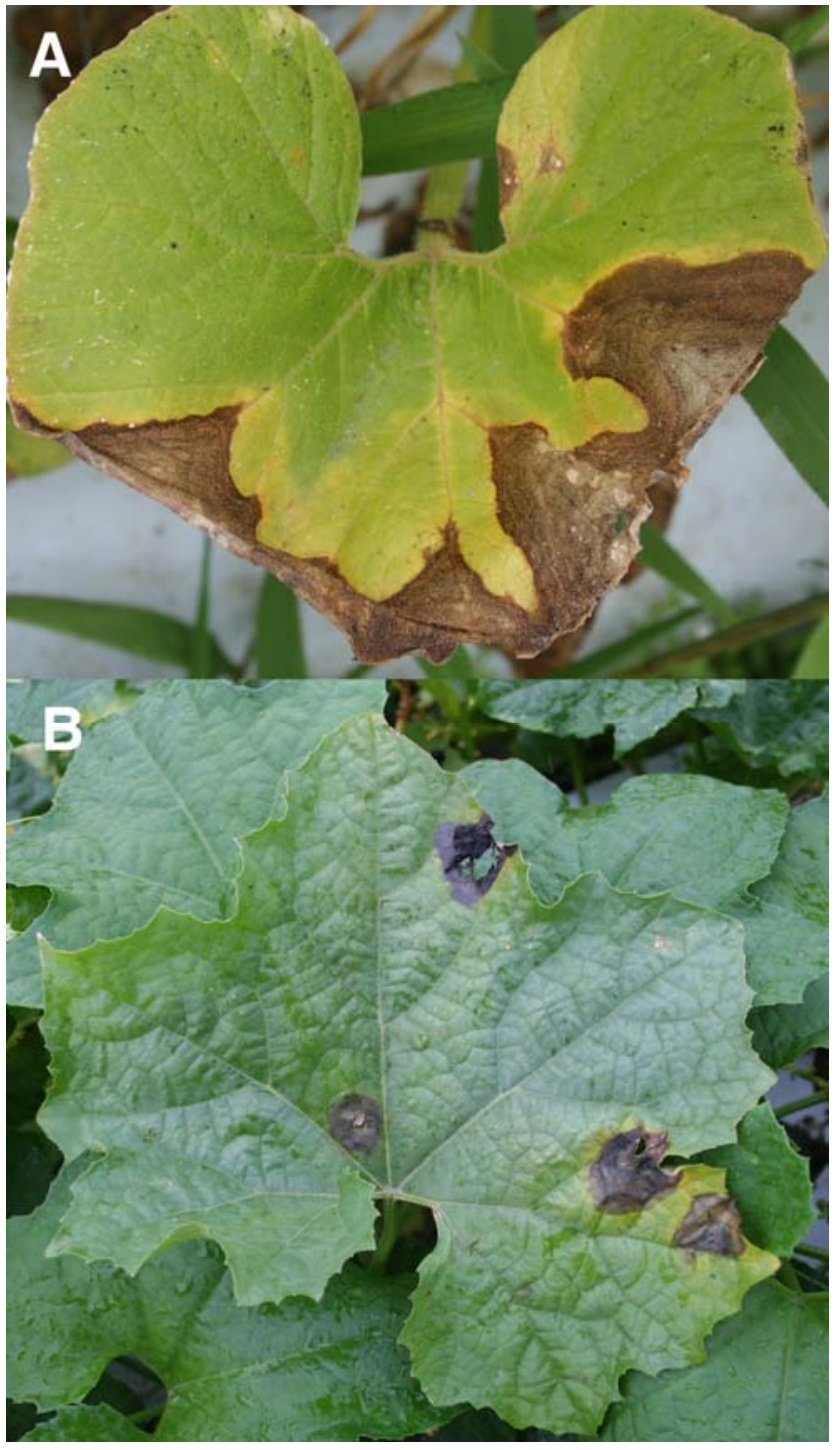

Fig. 2. Foliar symptoms of gummy stem blight. A, Four coalesced leaf spots on the lower margin and one spot on the upper margin of a leaf of giant pumpkin, Cucurbita maxima 'Big Max.' B, Several leaf spots on smooth loofah, Luffa cylindrica. 
also were less than foliar incidence on citron in each year. Watermelon cultivars consistently had high incidence and severity of foliar gummy stem blight $(\geq 89 \%)$ but a low incidence of crown cankers (1 to $22 \%$ ).

Pathogen recovery from leaves. Percent recovery of $D$. bryoniae from leaf spots resembling gummy stem blight was slightly greater in 2009 , when a mean of $89.9 \%$ of the 350 leaf spots cultured yielded colonies, than in 2008 , when $79.5 \%$ of 705 leaf spots yielded the pathogen. However, there was no significant difference between years and no year-cultivar interaction $(P \geq 0.24)$. Recovery was greatest from watermelon and citron and least from zucchini (Table 5). There were no differences in recovery among cultivars within species or horticultural types, except with summer squash. D. bryoniae was isolated from $94.2 \%$ of the leaf spots from Lioness yellow summer squash but only $50.9 \%$ of the leaf spots from Judgment III zucchini (Table 5). Recovery from the two watermelon cultivars was greater than from all Cucurbita cultivars except Hubbard and Lioness (Table 5). Percent recovery was less from Cucurbita moschata, C. maxima, and C. argyrosperma than the three cultivars of Citrullus (single-degree-of-freedom contrasts, $P \leq$ 0.004). In addition, recovery from $C$. moschata also was less than recovery from cucumber and melon $(P \leq 0.005)$. Percent recovery was moderately correlated with foliar severity (Pearson's correlation coefficient $=0.51, P=0.004)$. There was no significant correlation between percent recovery and incidence of foliar blight or cankers.

\section{Discussion}

In this field study in South Carolina, muskmelon was very susceptible to crown cankers, as previously reported $(4,5,17)$. Cankers were less frequent on honeydew, another horticultural type within Cucumis melo, than on muskmelon as previously noted (40). As in the study by Chiu and Walker (4), cankers also developed on watermelon, cucumber, Hubbard winter squash, bottle gourd, zucchini, and yellow summer squash, although host plants were not wounded in this study. The variation among years in canker incidence on cucumber and bottle gourd may explain why these hosts were not infected in the greenhouse inoculations done by Grossenbacher (9). Few smooth loofah plants had cankers in this study, in which the plants were not wounded, which was similar to the results of Grossenbacher (9), who wounded plants. Another loofah species, Luffa perforans, also appeared to be less susceptible than watermelon and muskmelon when stems were wounded and inocu-

Table 5. Mean percent recovery of Didymella bryoniae from leaves of 18 cucurbit cultivars in 2008 and $2009^{\mathrm{x}}$

\begin{tabular}{lc}
\hline Cultivar $^{\mathbf{y}}$ & Mean recovery $(\%)^{\mathbf{z}}$ \\
\hline Crimson Sweet & $99.8 \mathrm{a}$ \\
Mickey Lee & $99.8 \mathrm{a}$ \\
Ojakkyo & $98.0 \mathrm{ab}$ \\
Athena & $97.1 \mathrm{ab}$ \\
Rocio & $91.0 \mathrm{abc}$ \\
Marketmore & $84.8 \mathrm{abcd}$ \\
Colt & $91.8 \mathrm{abc}$ \\
Green Striped Cushaw & $75.8 \mathrm{bcd}$ \\
Hubbard & $85.4 \mathrm{abcd}$ \\
Big Max & $59.1 \mathrm{~cd}$ \\
Bugle & $55.8 \mathrm{~cd}$ \\
Cheese & $60.5 \mathrm{~cd}$ \\
Aladdin & $78.3 \mathrm{bcd}$ \\
Judgment III & $50.9 \mathrm{~d}$ \\
Lioness & $94.2 \mathrm{abc}$ \\
Taybelle PM & $78.6 \mathrm{bcd}$ \\
Loofah & $87.3 \mathrm{abcd}$ \\
Bottle gourd & $85.8 \mathrm{abcd}$ \\
\hline
\end{tabular}

${ }^{x}$ At each of six sampling times, 10 leaf pieces, each cut from one spot, were disinfested and cultured to recover $D$. bryoniae.

y Cultivars are listed in the same order as in Tables 1, 3, and 4.

${ }^{\mathrm{z}}$ Each value is the mean of six observations from four replications in the 2008 experiment and two replications in the 2009 experiment. Means with the same letters are not significantly different, based on least-squares means $t$ tests, $P \leq 0.01$. lated (7). Cankers developed on acorn squash in this study but not in the study by Chiu and Walker (4), who tested the heirloom 'Table Queen', a progenitor of 'Table Ace' used in this study (26). Both Cucurbita moschata cultivars (Cheese, an heirloom cultivar with round, ribbed, flat fruit and Bugle, a modern hybrid with typical bell-shaped butternut fruit) were completely resistant to crown cankers. No previous reports were found that indicated C. moschata was resistant to crown cankers.

The isolates of $D$. bryoniae used to inoculate cucurbits in this study originated from muskmelon and watermelon. It is possible that the greater severity observed on these hosts represented a host preference or greater virulence on the hosts of origin than on other cucurbits. Chiu and Walker (4) and dos Santos et al. (7) found that watermelon seedlings were more susceptible than squash seedlings to isolates of $D$. bryoniae originating from watermelon. This difference in host susceptibility also was observed with mature plants in this study. However, Zúniga (42) found slight differences between pumpkin and watermelon seedlings inoculated with isolates from pumpkin or squash. Because this study was done under field conditions with mature plants, and disease progressed over a period of 2 to 3 months, any differences in virulence on seedlings should have been negligible by the time the severity ratings were done.

C. argyrosperma, of which Green Striped Cushaw squash is one of the few known cultivars, was much more susceptible to cankers and foliar blight than the other three Cucurbita spp. and eight Cucurbita cultivars tested (26). This is the first study to document susceptibility of $C$. argyrosperma to gummy stem blight. The extreme susceptibility of this host to crown and stem cankers was unexpected, based on reports that other Cucurbita spp. and horticultural types were resistant to cankers, or cankers remained limited to the inoculation site $(4,9)$. Based on mitochondrial gene DNA sequences, $C$. argyrosperma and $C$. moschata are closely related (29). However, these two species differed greatly each year in susceptibility to the canker and foliar phases of gummy stem blight. Although severe, stem cankers did not kill C. argyrosperma plants, similar to observations of stem cankers on watermelon and other hosts $(3,4,24)$.

Watermelon plants had fewer cankers than expected based on previous reports $(4,9,12,24)$. In particular, canker incidence on watermelon was consistently less than on muskmelon and honeydew, in contrast to previous studies that included both watermelon and muskmelon $(4,9)$. Chiu and Walker (4) reported that cankers were more frequent on vines of muskmelon, watermelon, and cucumber that were wounded and inoculated in the field than on plants that were not wounded but exposed to natural inoculum. It is possible that the lower incidence of cankers on watermelon in this study was because the plants were not wounded when they were inoculated, as in some previous studies $(4,9)$.

Watermelon was much less susceptible to crown cankers than to foliar blight. Cultivated watermelon has a narrow genetic base; therefore, most cultivars likely show the same differential susceptibility to cankers and foliar blight (23). This difference in susceptibility to different symptoms of gummy stem blight implies that there may be genes in watermelon that confer partial resistance to the canker phase of gummy stem blight. Different genes that confer resistance to different phases or symptoms of a disease have been found in pepper, with two independent, dominant genes involved in resistance to stem blight and foliar blight caused by Phytophthora capsici (39). C. moschata and C. pepo also are likely to have genes that confer resistance to stem cankers.

PI accessions of citron have been shown to be less susceptible to gummy stem blight than watermelon accessions $(11,23)$. In this study, although incidence of plants with foliar blight on citron was as great as on watermelon (essentially $100 \%$ ), severity was only half as great in 2008 and 2009, when environmental conditions were favorable for foliar disease development. Thus, 'Ojakkyo' citron, which was bred for use as a rootstock to graft watermelon, also demonstrated reduced susceptibility to foliar blight.

Gummy stem blight development requires periods of leaf wetness and is promoted by moderate temperatures $(1,13)$. The en- 
hanced foliar disease development in 2009 did not appear to be directly related to the temperature and amounts of rainfall and supplemental moisture during that experiment. The canker phase of gummy stem blight was apparently affected less by environmental conditions than the foliar phase. As the crop develops, a canopy of leaves covers the crowns of cucurbits and shades the crown, reduces evaporation, and lengthens wetness periods (27). These factors may have stabilized the microclimate around the crown that allowed for consistent infection of susceptible hosts, despite considerable variation in leaf wetness and air temperature in the upper canopy.

D. bryoniae was recovered from 50 to $100 \%$ of leaf lesions on the different hosts. There was a general trend for greater recovery from hosts with more severe foliar blight. This trend may indicate that the pathogen could colonize more thoroughly the more susceptible hosts such as watermelon than less susceptible hosts such as squash. Another explanation is that the slightly lower rate of recovery in 2008 and from Cucurbita hosts may have been due to the presence of downy mildew on five Cucurbita cultivars in 2008. If sporulation of downy mildew was suppressed by the routine fungicide applications, some necrotic downy mildew lesions may have been cultured inadvertently for recovery of $D$. bryoniae.

Several important conclusions can be made from this study. First, Cucumis melo and Cucurbita argyrosperma were the most susceptible species across environments, varying in favorability for disease development in this South Carolina location. The canker phase of gummy stem blight consistently was more severe on these two species than on all other host species and genera. Likewise, foliar blight was more severe on Cucumis melo than on other species, except Citrullus lanatus. In contrast, Cucurbita moschata and C. pepo were the least susceptible species across years, even when environmental conditions favored development of cankers and blighting. The latter confirms the results of Sitterly (33), who considered yellow summer squash to be resistant to foliar gummy stem blight. No fungicides were applied in this study that would have reduced development of gummy stem blight. Thus, Bugle, Lioness, Judgment III, and Taybelle PM appear to have some level of resistance to gummy stem blight. Hubbard and Cheese squash and smooth loofah also displayed less susceptibility to gummy stem blight than the most susceptible cultivars.

Susceptibility to crown cankers or foliar blight varied significantly among species within the genera Cucurbita, Cucumis, and Citrullus in one or more years. The severe and uncharacteristic susceptibility of $C$. argyrosperma to gummy stem blight compared with the other three Cucurbita spp. included in this study has been discussed. In addition, Cucumis sativus was less susceptible to crown cankers than $C$. melo every year. Third, citron was less susceptible than watermelon to foliar blight in the autumn, when environmental conditions favored disease development. Thus, it appears that generalizations about the susceptibility of cucurbits to gummy stem blight should be limited to differences among species or horticultural types.

The hosts that had the greatest number of cankered plants are also likely to be the hosts on which $D$. bryoniae would survive the longest on crop debris. These hosts include muskmelon and Green Striped Cushaw squash, as well as bottle gourd and honeydew. In a previous study, D. bryoniae survived longer than 2 years on muskmelon crown cankers (17). Muskmelon growers who find gummy stem blight cankers on plants should follow a 3-year rotation to ensure that soilborne inoculum of $D$. bryoniae is eliminated before susceptible cucurbits are grown.

Information from this study on differences in susceptibility among cucurbits could be used to reduce or refine fungicide applications. For example, spray intervals could be lengthened on cucurbits such as summer and acorn squash that are less susceptible to cankers and blighting. Protectant fungicides such as chlorothalonil may be sufficiently effective on these squash that purchasing more expensive systemic fungicides may not be warranted. Fungicide applications to butternut squash, which was resistant to crown cankers and less susceptible to foliar blight, may potentially be delayed until flowering, because the fruit of bell-shaped cultivars such as Bugle is susceptible to black rot, the fruit rot phase of gummy stem blight (41). On the other hand, the greater susceptibility of watermelon and melons to foliar blight in the absence of fungicide applications demonstrates that regular fungicide applications may be required on these crops in favorable environments for gummy stem blight $(14,15)$.

\section{Acknowledgments}

I thank E. L. Fillippeli, V. B. DuBose, G. V. Baccari, A. W. Lassiter, and J. A. Dufault for technical assistance; and J. R. Rieck, Department of Mathematics, Clemson University, for statistical advice.

\section{Literature Cited}

1. Arny, C. J., and Rowe, R. C. 1991. Effects of temperature and duration of surface wetness on spore production and infection of cucumbers by Didymella bryoniae. Phytopathology 81:206-209.

2. Bala, G., and Hosein, F. 1986. Studies on gummy stem blight disease of cucurbits in Trinidad. Trop. Agric. (Trinidad) 63:195-197.

3. Chester, F. D. 1891. Notes on three new or noteworthy diseases of plants. Bull. Torrey Bot. Club 18:371-374.

4. Chiu, W. F., and Walker, J. C. 1949. Physiology and pathogenicity of the cucurbit black-rot fungus. J. Agric. Res. 78:589-615.

5. Crinò, P., Lo Bianco, C., Rouphael, Y., Colla, G., Saccardo, F., and Paratore, A. 2007. Evaluation of rootstock resistance to Fusarium wilt and gummy stem blight and effect on yield and quality of a grafted 'Inodorus' melon. HortScience 42:521-525.

6. de Neergaard, E. 1989. Studies of Didymella bryoniae (Auersw.) Rehm: development in the host. J. Phytopathol. 127:107-115.

7. dos Santos, G. R., Ferreira, M. A. S. V., Pessoa-Filho, M. A. C. P., Ferreira, M. E., and Café-Filho, A. C. 2009. Host specificity and genetic diversity of Didymella bryoniae from Cucurbitaceae in Brazil. J. Phytopathol. 157:265273.

8. Food and Agriculture Organization of the United Nations. 2013. FAOSTAT, Production.

9. Grossenbacher, J. G. 1909. A Mycosphaerella wilt of melons. N. Y. (Geneva) Agric. Exp. Stn. Tech. Bull. 9:193-229.

10. Grube, M., Fürnkranz, M., Zitzenbacher, S., Huss, H., and Berg, G. 2011. Emerging multi-pathogen disease caused by Didymella bryoniae and pathogenic bacteria on Styrian oil pumpkin. Eur. J. Plant Pathol. 131:539-548.

11. Gusmini, G., Song, R. H., and Wehner, T. C. 2005. New sources of resistance to gummy stem blight in watermelon. Crop. Sci. 45:582-588.

12. Jensen, B. D., Massawe, A., and Swai, I. S. 2011. First report of gummy stem blight caused by Didymella bryoniae on watermelon and confirmation of the disease on pumpkin in Tanzania. Plant Dis. 95:768.

13. Keinath, A. P. 1995. Fungicide timing for optimum management of gummy stem blight epidemics on watermelon. Plant Dis. 79:354-358.

14. Keinath, A. P. 2000. Effect of protectant fungicide application schedules on gummy stem blight epidemics and marketable yield of watermelon. Plant Dis. 84:254-260.

15. Keinath, A. P. 2001. Effect of fungicide applications scheduled to control gummy stem blight on yield and quality of watermelon fruit. Plant Dis. 85:53-58.

16. Keinath, A. P. 2002. Survival of Didymella bryoniae in buried watermelon vines in South Carolina. Plant Dis. 38:32-38.

17. Keinath, A. P. 2008. Survival of Didymella bryoniae in infested muskmelon crowns in South Carolina. Plant Dis. 92:1223-1228.

18. Keinath, A. P. 2011. From native plants in Central Europe to cultivated crops worldwide: The emergence of Didymella bryoniae as a cucurbit pathogen. HortScience 46:532-535.

19. Keinath, A. P., and DuBose, V. B. 2004. Evaluation of fungicides for prevention and management of powdery mildew on watermelon. Crop Prot 23:35-42.

20. Keinath, A. P., and Duthie, J. A. 1998. Yield and quality reductions in watermelon due to anthracnose, gummy stem blight, and black rot. Pages 77-90 in: Recent Research Developments in Plant Pathology, Vol. 2. Research Signpost, Trivandrum, India.

21. Keinath, A. P., Fillippelli,, E. L., Baccari, G. V., and DuBose, V. B. 2010. Susceptibility of 15 cultivars of watermelon, melon, squash, pumpkin, and bottle gourd to gummy stem blight, 2009. Plant Dis. Manage. Rep. 4:V120. Online publication. doi:10.1094/PDMR04

22. Keinath, A. P., Farnham, M. W., and Zitter, T. A. 1995. Morphological, pathological, and genetic differentiation of Didymella bryoniae and Phoma spp. isolated from cucurbits. Phytopathology 85:364-369.

23. Levi, A., Thomas, C. E., Keinath, A. P., and Wehner, T. C. 2001. Genetic diversity among Citrullus lanatus and Citrullus colocynthis accessions. Genet. Res. Crop Evol. 48:559-566.

24. Orton, W. A., and Meier, F. C. 1922. Diseases of watermelons. U. S. Dept. Agric. Farm. Bull. 1277.

25. Punithalingam, E., and Holliday, P. 1972. Didymella bryoniae. CMI Descriptions of Pathogenic Fungi and Bacteria, No. 332. Commonwealth Mycological Institute, Kew, Surry, UK. 
26. Robinson, R. W., and Decker-Walters, D. S. 1997. Cucurbits. CAB International, New York.

27. Rotem, J., and Palti, J. 1969. Irrigation and plant diseases. Annu. Rev. Phytopathol. 7:267-288.

28. Roy, A. J. 1967. Some fungi from Almora. Indian Phytopathol. 20:340-348.

29. Sanjur, O. I., Piperno, D. R., Andres, T. C., and Wessel-Beaver, L. 2002. Phylogenetic relationships among domesticated and wild species of Cucurbita (Cucurbitaceae) inferred from a mitochondrial gene: implications for crop plant evolution and areas of origin. Proc. Natl. Acad. Sci. USA 99:535540.

30. Santner, T. J., and Duffy, D. E. 1989. The Statistical Analysis of Discrete Data. Springer-Verlag, New York.

31. Schenck, N. C. 1968. Epidemiology of gummy stem blight (Mycosphaerella citrullina) on watermelon: ascospore incidence and disease development. Phytopathology 58:1420-1422.

32. Silva, E. S., Palangana, F. C., Goto, R., Furtado, E. L., and Fernandes, D. M. 2012. Net melon resistance to Didymella bryoniae according to grafting and potassium levels. Summa Phytopathologica 38:139-143.

33. Sitterly, W. R. 1969. Effect of crop rotation on cucumber gummy stem blight. Plant Dis. Rep. 53:417-419.

34. Sitterly, W. R., and Keinath, A. P. 1996. Gummy stem blight. Page 27 in: Compendium of Cucurbit Diseases. T. A. Zitter, C. E. Thomas, and D. L. Hopkins, eds. American Phytopathological Society St. Paul, MN.

35. St. Amand, P. C., and Wehner, T. C. 1991. Crop loss to 14 diseases of cu- cumber in North Carolina from 1983 to 1988. Cucurbit Genet. Coop. Rep. $14: 15-17$

36. Sudisha, J., Niranjana, S. R., Umesha, S., Prakash, H. S., and Shekar Shetty, H. 2006. Transmission of seed-borne infection of muskmelon by Didymella bryoniae and effect of seed treatments on disease incidence and fruit yield. Biol. Control 37:196-205.

37. Thaung, M. M. 2008. Pathologic and taxonomic analysis of leaf spot and tar spot diseases in a tropical dry to wet monsoon ecosystem of lowland Burma. Australas. Plant Pathol. 37:180-197.

38. van Steekelenburg, N. A. M. 1983. Epidemiological aspects of Didymella bryoniae, the cause of stem and fruit rot of cucumber. Neth. J. Plant Pathol. 89:75-86.

39. Walker, S. J., and Bosland, P. W. 1999. Inheritance of Phytophthora root rot and foliar blight resistance in pepper. J. Am. Soc. Hortic. Sci. 124:14-18.

40. Zhang, J. X., Bruton, B. D., Miller, M. E., and Isakeit, T. 1999. Relationship of developmental stage of cantaloupe fruit to black rot susceptibility and enzyme production by Didymella bryoniae. Plant Dis. 83:1025-1032.

41. Zitter, T. A. 1996. Black rot. Page 48 in: Compendium of Cucurbit Diseases. T. A. Zitter, C. E. Thomas, and D. L. Hopkins, eds. American Phytopathological Society, St. Paul, MN.

42. Zúniga, T. L. 1999. Gummy stem blight (Didymella bryoniae) of cucurbits: pathogen characterization and inheritance of resistance in melon (Cucumis melo). Ph.D. dissertation, Department of Plant Pathology, Cornell University, Ithaca, NY. 